TITLE:

\title{
Effects of thorough mastication on postprandial plasma glucose concentrations in nonobese Japanese subjects(Abstract_要 旨)
}

$\operatorname{AUTHOR}(\mathrm{S})$ :

Suzuki, Hidehiko

\section{CITATION:}

Suzuki, Hidehiko. Effects of thorough mastication on postprandial plasma glucose concentrations in nonobese Japanese subjects. 京都大学, 2006, 博士(医学)

ISSUE DATE:

2006-03-23

URL:

http://hdl.handle.net/2433/143859

RIGHT: 


\begin{tabular}{|c|c|}
\hline 名 & $\begin{array}{ll}\text { ひで } & \text { ひこ } \\
\text { 英 } & \text { 彦 }\end{array}$ \\
\hline 学位(専攻分野) & 士（医 \\
\hline 学位記 番号 & 医 博 第 2979 号 \\
\hline 学位授与の日付 & 平成 18 年 3 月 23 日 \\
\hline 学位授与の要件 & 学位規則第 4 条第 1 項該当 \\
\hline 研究科 · 専攻 & 医 学 研 究 科 内 科 系 専 攻 \\
\hline 学位論文題目 & $\begin{array}{l}\text { Effects of thorough mastication on postprandial plasma glucose } \\
\text { concentrations in nonobese Japanese subjects. } \\
\text { （徹底咀賈が食後血糖值に与える影響 : 非肥満日本人における検討） }\end{array}$ \\
\hline
\end{tabular}

\begin{abstract}
論文.内容の 要旨
2 型糖尿病の主な病態はインスリン分泌不全とインスリン抵抗性であり, 日本人ではインスリン分泌不全が多く認められ，

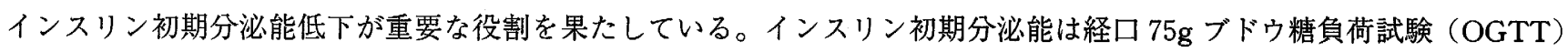
において，30分間でのインスリン值増加分と血糖值増加分の比率（insulinogenic index：I.I.）として評価される。一方，食 事負荷試験（MTT）はブドウ糖のみでなく他の栄養素を含んだ負荷であるため，日常の食後代謝をよく反映している。今 回，MTTの I. I. がインスリン初期分泌能の評価に妥当であるかを OGTT の I. I. と比較検討した。次に食事負荷後の糖代 謝を, 徹底咀嚼と通常咀嚼で比較検討し, 徹底咀嚼が糖代謝に及ぼす影響を検討した。

26人の対象者を，16人の正常耐糖能群（ $\mathrm{N}$ 群）と10人の2型糖尿病・扔よび予備群（Pre+ DM 群）（2 型糖尿病患者, 耐 糖能異常者, 第 1 親等に 2 型糖尿病患者を有する者）に分け，ハンバーグとライスから成る $385 \mathrm{kcal}$ の試験食を，ひとくち 30 秒嘴む徹底咀噮と 10 秒踤む通常咀嚼の 2 機会に参加するクロスオーバーデザインで血糖值，インスリン值を食後 3 時間ま で測定した。食事時間の長短が交絡因子となる可能性を除外するために, 通常咀噮では10秒嘴んだ後に20秒の中断を設け, 双方の食事時間を8分に揃えた。
\end{abstract}

OGTT, MTT 双方に参加した N 群 14 人, Pre+DM 群10人は, 両試験ともに血糖值, インスリン值の頂值は N 群が 30 分, Pre+DM群が60分であり，両試験ともに30分のインスリン値，I.I. はN 群の方がPre+DM群よりも有意に高かった。 両試験の I. I. を比較すると，N 群では OGTTの方がMTTよりも大きく，Pre+DM 群では逆にMTT の方が大きかった。 両試験の I. I. には $\mathrm{r}=0.53, \mathrm{p}<0.01$ と有意な正相関が得られた。したがって, MTT はインスリン初期分泌能の評価に有 用であり，I.I. によりPre+DM 群をNGT 群から識別できることが示された。MTT で前値，120分值の測定に加え，30分 值を測ることはインスリン初期分泌能評価に有用と言える。

次に $\mathrm{N}$ 群 16 人では徹底咀夁を行うと, 通常咀嚼に比ベ, インスリンの総曲線下面積は同一で, 食後 90 分, 120 分の血糖值, ならびに総血糖曲線下面積が有意に低下した。Pre+DM 群10人では徹底咀鲅を行うと, 通常咀嚼に比べ, 食後血糖値, イ ンスリン值ともに有意に増大した。以上より, 膵 $\beta$ 細胞機能が十分に保たれている $\mathrm{N}$ 群では, 徹底咀嚼によりインスリン 初期分泌能が増強され食後血糖値が低下すると考えられ，この群では徹底咀嚼は食後高血糖の抑制に有効であると思われる。 一方, 膵 $\beta$ 細胞の予備能が低下しているPre $+\mathrm{DM}$ 群では, インスリン初期分泌能が増強されないために食後血糖值が上 昇すると考えられる。咀嚼を十分に行うと早く満腹感を生じることが報告されている。本研究では咀嚼それ自体を見るため 総摂取量, 食事時間を一致させているが, 日常生活では徹底咀㘉により満腹感で総掑取量を抑えることで, この群に打ける 食後高血糖を抑制すべきであろう。

本研究により，食事負荷におけるインスリン初期分泌能評価の有用性，抢上び徹底咀嚼による食後糖代謝の実態が明らか になった。 
食後高血糖は，患者数が急速に増加している糖尿病の発症と合併症進展に重要で，また咀嚼は食後糖代謝に影響を与える と報告されている。

本研究で，申請者は日常の食後代謝を反映する食事負荷試験（MTT）に注目し，MTT30 分のインスリン増加分と血糖 増加分の比率 insulinogenic index（II）がインスリン初期分泌能評価に妥当であるかをブドウ糖負荷試験（OGTT）の II と比較した。次に徹底咀嚼が糖代謝に与える影響を正常耐糖能群（N 群）と 2 型糖尿病および予備群（Pre+DM群）(軽 症 2 型糖尿病患者，耐糖能異常者，第 1 親等に 2 型糖尿病患者がいる者)でMTTを用いて検討した。

OGTT, MTT 試験ともにインスリン值のピーク時間は各群で一致し，Iは $\mathrm{N}$ 群の方が Pre+DM 群より有意に高く，両 IIに有意な正相関が得られ，MTTに抢ける』の有用性が示された。

徹底咀嚼は通常咀嚼に比べ， $N$ 群の II は有意に高く食後血糖值は有意に低下したが, Pre+DM 群の II は不变で食後血糖 值は有意に増大した。膵 $\beta$ 細胞機能が十分に保たれている $\mathrm{N}$ 群では徹底咀嚼によりインスリン初期分泌能が増強されたが, Pre+DM 群では低下があるためと考えられた。N群では徹底咀嚼による食後糖代謝の改善が認められたが, Pre+DM群 では徹底咀嚼による食後糖代謝改善の効果は認められなかった。

以上の研究は徹底咀嚼の食後糖代謝へ及ほすす効果の解明に貢献し，糖尿病の病態の理解に寄与するところが多い。したが って, 本論文は博士 (医学) の学位論文として価值あるものと認める。

なお，本学位授与申請者は，平成17年12月 20 日実施の論文内容とそれに関連した試問を受け，合格と認められたものであ る。 